\title{
Dissenting Opinions Hakim Mahkamah Konstitusi Terhadap Pembatalan Peraturan Daerah Kabupaten/Kota Oleh Menteri Dalam Negeri Dikaitkan Dengan Pasal 24A Ayat (1) UUD 1945 (Putusan Mahkamah Konstitusi Nomor:137/PUU-XIII/2015)
}

\author{
Kantrey Sugiarto ${ }^{1}$, Heru Drajat Sulistyo ${ }^{2}$ \\ Fakultas Hukum, Universitas Soerjo, Jl. Cери Km.3, Ngawi, 63218 \\ E-mail:kantrey23@gmail.com \\ Fakultas Hukum, Universitas Soerjo, Jl. Сери Km.3, Ngawi, 63218 \\ E-mail: herudrajat@gmail.com
}

\begin{abstract}
On April 4, 2017, the Panel of Judges of the Constitutional Court read out the decision on a judicial review of the laws of the Regional Government registered with case number 137 / PUU-XIII / 2015. Of the 9 (nine) judges who tried the case, there were 4 (four) judges who did dissenting opinions. With the Dissenting Opinion in this decision can be used as one of the quality parameters of the decision in fulfilling the sense of justice of the community, because it can be assessed the quality of thought of each judge and know the inner atmosphere that occurs during the judge deliberation meeting which is one of the crucial stages before a court ruling. The description of the activities carried out is, first to identify the facts of the law and to eliminate the irrelevant matters to establish legal issues to be solved. Second, collecting legal materials that are relevant to legal issues that are discussed so as to be able to solve these legal issues. Third, review legal issues submitted based on the materials collected. Fourth, draw conclusions in the form of arguments that answer legal issues. Fifth, provide text based on the arguments built in the conclusions.
\end{abstract}

Keywords - : Dissenting Opinion; Constitutional Court Decision; Cancellation of Regional Regulation; Minister of Home Affairs.

\section{PENDAhuluan}

\section{A. Latar Belakang}

Pada tanggal 4 April 2017, Majelis Hakim Mahkamah Konstitusi membacakan putusan atas permohonan uji materiil undangundang Pemerintah Daerah yang teregistrasi dengan nomor perkara 137/PUU-XIII/2015. Putusan tersebut mengabulkan sebagian permohonan pemohon, salah satunya yaitu terkait pencabutan pasal 251 ayat (3) Undang- Undang Nomor 23 Tahun 2014 Tentang Pemerintahan Daerah (selanjutnya disebut UU Pemda 2014) yang pada pokoknya menyatakan bahwa Menteri ${ }^{1}$ dapat membatalkan perda kabupaten/kota selama gubernur tidak bisa menjalankan ketentuan pasal 251 ayat (2) UU Pemda 2014. Dalam putusan Mahkamah Konstitusi diatas, majelis hakim berpendapat bahwa kewenangan pembatalan peraturan daerah kabupaten/kota ada pada Mahkamah Agung sebagaimana dimaksud dalam Pasal 24A ayat (1) UUD 1945.

Meskipun pencabutan pasal tersebut sudah didasari salah satunya dengan pasal 24A ayat (1) UUD 1945, ternyata dari 9 (sembilan) orang hakim majelis yang menyidangkan perkara ini, terdapat 4 (empat) orang hakim yang melakukan dissenting opinions (pendapat berbeda). Hal ini bisa menjadi gambaran awal bahwa ketika dalam permusyawaratan majelis hakim sebelum dikeluarkannya putusan di atas tidak ditemukanya kata mufakat dan harus dilakukan secara voting. ${ }^{2}$ Fakta hukum inilah yang menjadi titik tolak ketertarikan peneliti untuk menganalis dissenting opinions 4 (empat) orang anggota majelis hakim yang tertuang dalam putusan perkara nomor: 137/PUU-XIII/2015 lebih lanjut untuk memberikan perskripsi terhadap kualitas putusan yang dimaksud. Dissenting opinions sendiri merupakan suatu hal yang diperbolehkan sejak berlakunya undang-undang Kekuasaan Kehakiman, terdapat suatu konvensi diantara para anggota suatu majelis hakim jika dalam sidang permusyawaratan majelis hakim tidak tercapai kata mufakat maka pendapat hakim minoritas yang berbeda dengan hasil rapat permusyarakatan hakim wajib dimuat dalam putusan dan merupakan bagian yang tidak terpisahkan dari putusan tersebut. Dengan adanya Dissenting Opinion dalam putusan ini dapat digunakan sebagai salah satu parameter kualitas putusan dalam memenuhi rasa keadilan masyarakat, karena dapat dinilai kualitas pemikiran tiap-tiap hakim dan mengetahui suasana batin yang terjadi selama berlangsungnya rapat permusyawaratan hakim yang merupakan salah satu tahap krusial sebelum dihasilkannya suatu putusan pengadilan.

\footnotetext{
${ }^{1}$ dalam hal ini adalah Menteri Dalam Negeri sebagaimana yang dimaksud dalam pasal 1 angka 44 UU Pemda 2014.

${ }^{2}$ Dalam UU No.5 tahun 2004 tentang perubahan UU No.14 tahun 1970 yang telah disahkan DPR-RI bulan Desember 2003, mencantumkanpasal 19: (4) dalam sidang permusyawaratan, setiap hakim wajib menyampaikan pertimbangan atau pendapat tertulis terhadap perkara yang sedang diperiksa dan menjadi bagian yang tak terpisahkan dari putusan. (5) dalam hal sidang permusyawaratan tidak dapat dicapai kata mufakat bulat, pendapat hakim yang berbeda wajib dimuat dalam putusan.
} 
Penganalisisan Dissenting Opinion 4 (empat) orang anggota majelis hakim dalam putusan perkara nomor: 137/PUUXIII/2015 akan dilakukan sesuai dengan karakteristik ilmu hukum sebagai ilmu yang bersifat preskriptif dan terapan dalam skim penelitian dosen pemula dengan judul "Dissenting Opinions Hakim Mahkamah Konstitusi Terhadap Pembatalan Peraturan Daerah Kabupaten/Kota Oleh Menteri Dalam Negeri Dikaitkan Dengan Pasal 24a Ayat (1) UUD 1945 (Putusan Mahkamah Konstitusi Nomor:137/PUU-XIII/2015)."

\section{B. Rumusan Masalah}

a. Apa yang menjadi pertimbangan hakim dalam amar putusan perkara nomor: 137/PUU-XIII/2015?

b. Apakah dasar dissenting Opinion 4 (empat) orang anggota majelis hakim Mahkamah Konstitusi dalam putusan perkara nomor: 137/PUU-XIII/2015 sesuai dengan UUD 1945 ?

\section{Batasan Penelitian}

Mengacu pada latar belakang masalah tersebut di atas perlu adanya pembatasan masalah agar penelitian yang sudah dilakukan dapat diidentifikasi secara efektif, agar tidak terlalu luas dan berpusat pada masalah-masalah sebagai berikut.

a. Menganalisis pertimbangan hakim dalam amar putusan perkara nomor: 137/PUU-XIII/2015.

b. menganalisa dasar dissenting Opinion 4 (empat) orang anggota majelis hakim Mahkamah Konstitusi dalam putusan perkara nomor: 137/PUU-XIII/2015 dikaitkan dengan UUD 1945.

\section{KAJIAN PUSTAKA}

\section{A. Dissenting Opinion Hakim Dalam Putusan Pengadilan}

Kebebasan hakim dalam melakukan penemuan kebenaran materiil dan menyampaikan pendapat sebagaimana diatur dalam Undang-Undang Kekuasaan Kehakiman, pada dasarnya merupakan bentuk ekspresi keyakinan, filsafat, pandangan, kepribadian, serta keilmuan seorang hakim dalam memutus perkara. Kebebasan inilah yang akan menimbulkan dissenting opinion (pendapat berbeda) dalam musyawarah pengambilan keputusan oleh majelis hakim. Terjadinya dissenting opinion antara hakim dalam memutus suatu perkara tidaklah bertentangan dengan peraturan perundang-undangan yang ada, sebagaimana diungkapkan di atas, yaitu pada Pasal 14 ayat (2) Undang-Undang Kekuasaan Kehakiman yang menyatakan bahwa "Dalam sidang permusyawaratan, setiap hakim wajib menyampaikan pertimbangan atau pendapat tertulis terhadap perkara yang sedang diperiksa dan menjadi bagian yang tidak terpisahkan dari putusan."3 Dilanjutkan dengan yang teruang pada ayat (3) nya menyatakan bahwa "Dalam hal sidang permusyawaratan tidak dapat dicapai mufakat bulat, pendapat hakim yang berbeda wajib dimuat dalam putusan". 4

Dissenting opinion dalam suatu putusan dapat terjadi pula karena adanya kebebasan hakim dalam menentukan metode penafsiran hukum, aliran penemuan hukum, dan proses penalaran hukum yang harus dimuat dalam pertimbangan putusan yang bisa menjadikan timbulnya interpretasi yang berbeda antar anggota majelis hakim.

"Dalam proses pembuatan putusan, hakim harus mempertimbangkan segala aspek yang bersifat yuridis, filosofis dan sosiologis, sehingga keadilan yang ingin dicapai, diwujudkan, dan dipertanggungjawabkan dalam putusan hakim adalah keadilan yang berorientasi pada keadilan hukum (legal justice), keadilan moral (moral justice), dan keadilan masyarakat (social justice).",

Melalui teknis dissenting opinion, majelis hakim yang memiliki suara yang mayoritas dalam memeriksa suatu perkara yang di sidangkan akan lebih berhati-hati dalam menerapkan sumber-sumber hukum yang dijadikan sebagai dasar dalam mempertimbangkan putusan. Hal ini juga yang harus diperhatikan oleh hakim yang menggunakan yurisprudensi sebagai sumber hukum untuk melakukan kajian terhadap pertimbangan hukum dalam yurisprudensi tersebut yang disesuaikan dengan kondisi sosial masyarakat.

\section{B. Mahkamah Konstitusi}

\section{Putusan Mahkamah Konstitusi}

Sejak berdiri pada tahun 2003, Mahkamah Konstitusi di bentuk sebagai satu-satunya lembaga yang menjadi yang salah satu kewenagannya adalah sebagai pengawal dan penafsir Undang-Undang Dasar, sebagaimana yang tertuang dalam UUD 1945 yang menyatakan bahwa "Mahkamah Konstitusi berwenang mengadili pada tingkat pertama dan terakhir yang putusannya bersifat final untuk menguji undang-undang terhadap Undang- Undang Dasar,......" 6 . Selain kewenangan tersebut, ada 3 kewenangan lainnya dan satu kewajiban Mahkamah Konstitusi dalam UUD 1945, yaitu Memutus sengketa kewenangan lembaga negara yang kewenangannya diberikan oleh Undang-Undang Dasar Negara Republik Indonesia Tahun 1945, memutus pembubaran partai politik dan memutus perselisihan tentang hasil pemilihan umum serta putusan atas

\footnotetext{
${ }^{3}$ Pasal 14 ayat (2) Undang-Undang Republik Indonesia Nomor 48 Tahun 2009 Tentang Kekuasaan Kehakiman, Lembaran Negara Nomor 157 Tahun 2009; Tambahan Lembaran Negara Nomor 5076 
semua kewenagan tersebut bersifat final. Kewajiban Mahkamah Konsitusi, sebagaimana di maksud di atas adalah wajib memberikan putusan atas pendapat Dewan Perwakilan Rakyat mengenai dugaan pelanggaran oleh Presiden dan/atau Wakil Presiden menurut Undang-Undang Dasar.

Produk dari 4 kewenagan Mahkamah Konstitusi merupakan suatu putusan, seperti yang sudah di sebut sebelumnya, putusan tersebut bersifat final dan mengikat. Hal ini dapat dipahami bahwa sejak dibacakannya putusan oleh Hakim Konstitusi maka putusan tersebut telah berkekuatan hukum tetap (in kracht), sehingga tidak ada lagi akses bagi para pihak untuk melakukan upaya hukum. Sifat putusan Mahkamah Konstitusi tersebut bertujuan juga sebagai upaya dalam menjaga wibawa peradilan konstutusional. Jika peradilan konstitusi mengakomodasi adanya upaya hukum para phak, maka tidak akan ada bedannya dengan peradilan umum.

\section{Hakim Mahkamah Konstitusi}

Presiden selaku kepala negara, secara administratif ketatanegaraan mempunyai tugas untuk mengangkat/memberhentikan Hakim Mahkamah Konstitusi yang berjumlah 9 (sembilan orang). Namun, bukan berarti kesembilan hakim tersebut seluruhnya di tunjuk oleh presiden. Ada 3 (tiga) lembaga Negara yang masing-masing di beri kewenangan untuk mengusulkan tiga orang untuk menempati posisi sebagai Hakim Mahkamah Konstitusi, yaitu Mahkamah Agung, DPR dan Presiden.

Sembilan orang hakim konstitusi diisi oleh calon yang dipilih oleh 3 lembaga, yaitu 3 (tiga) orang oleh Dewan Perwakilan Rakyat, 3 (tiga) orang oleh Presiden, dan 3 (tiga) orang oleh Mahkamah Agung4. Jika terdapat lowongan jabatan, maka lembaga yang akan mengisi lowongan tersebut adalah lembaga darimana pencalonan hakim sebelumnya berasal. ${ }^{7}$

Dengan adanya keterlibatan ketiga lembaga Negara yang mencakup cabang kekuasaan eksekutif, legislative, dan yudikatif tersebut dalam rekruitmen hakim konstitusi dapat dijamin adanya keseimbangan kekuatan antar cabang-cabang kekuasaan negara tersebut dan sekaligus pula menjamin netralitas dan imparsialitas MK dalam hubungan antar lembaga negara ${ }^{8}$

Lebih lanjut lagi, Prof. Dr. Jimly Asshiddiqie, SH. menggambarkan bahwa sembilan hakim Mahkamah Konstitusi ibarat sebuah institusi yang berdiri sendiri. Di sini, dapat tarik suatu pemahaman bahwa suatu putusan hakim mahkamah konstitusi merupakan suatu penafsiran masing-masing hakim dalam mencapai suatu putusan. Jika dalam musyawarah hakim sebelum pembacaan putusan terjadi perbedaan, maka akan ditempuh jalan musyawarah, misal belum tersatukan pula perbedaan yang ada, langkah terakhir adalah dengan pengambilan suara terbanyak. Suara terbanyak akan menjadi putusan suatu perkara yang di sidangkan, sedangkan suara minoritas, masing-masing akan dicantumkan dalam putusan sebagai dissenting opinion.

\section{Kerangka Putusan perkara nomor: 137/PUU-XIII/20159}

a) Kepala Putusan :

i. Judul

ii. Frasa

iii. Pembukaan

iv. Identitas Pemohon

v. Keterangan

[1.2] Membaca permohonan para Pemohon;

Mendengar keterangan para Pemohon;

Mendengar dan membaca keterangan Presiden;

Mendengar dan membaca keterangan Dewan Perwakilan Daerah;

Mendengar keterangan saksi dan ahli para Pemohon;

Memeriksa bukti-bukti surat/tertulis para Pemohon;

Membaca kesimpulan para Pemohon

b) Duduk Perkara :

i. pendaftaran perkara: [2.1] Menimbang bahwa para Pemohon ....dst.

ii. Posita Permohonan :

I. PENDAHULUAN

II. KEWENANGAN MAHKAMAH

III. KEDUDUKAN HUKUM LEGAL STANDING PARA PEMOHON

IV. POKOK PERMOHONAN

A. Pengaturan pembagian klasifikasi urusan pemerintahan dalam pasal 9, pasal 11, pasal 12, pasal 13, pasal 14, pasal 15, pasal 16, pasal 17, pasal 21, pasal 27, dan pasal 28 uu nomor 23 tahun 2014 merupakan bentuk sentralisme kekuasaan, pembatasan kewenangan pemerintahan daerah kabupaten/kota, dan model otonomi fiktif

\footnotetext{
${ }^{7}$ http://www.jimlyschool.com/read/analisis/238/kedudukan-mahkamah-konstitusi-dalam-struktur-ketatanegaraan-indonesia/

${ }^{8}$ ibid.

${ }^{9}$ Penyajian kerangka dalam sub bab ini merupakan improvisasi peneliti untuk menggambarkan secara ringkas salah satu sumber bahan hukum yang di jadikan batu uji dalam penelitian ini.
} 
B. Para pemohon tidak dapat melaksanakan haknya untuk memajukan dirinya dalam memperjuangkan haknya secara kolektif untuk membangun masyarakat bangsa dan negara sebagaimana dijamin dalam pasal 28c ayat (2) uud 1945.

C. Ketentuan pasal 14 ayat (1), ayat (2), ayat (3), dan ayat (4), pasal 27 ayat (1), ayat (2) dan pasal 28 ayat (1) dan ayat (2) undang - undang nomor 23 tahun 2014 tentang pemerintahan daerah menyebabkan ketidakadilan dan ketidakselarasan dalam pengelolaan sumberdaya alam dan sumberdaya daerah lainnya karenanya bertentangan dengan pasal 18 ayat (2) dan ayat (5) junctis pasal 18a ayat (2) dan pasal 28c ayat (2) uud 1945

D. Pasal 251 ayat (2), ayat (3), ayat (8), dan ayat (4) sepanjang frasa “...pembatalan perda kabupaten/kota dan peraturan bupati/walikota sebagaimana dimaksud pada ayat (2) ditetapkan dengan keputusan gubernur sebagai wakil pemerintah pusat..."Undang-undang nomor 23 tahun 2014 bertentangan dengan pasal 18 ayat (6) junctis pasal 28d ayat (1) dan pasal 24a ayat (1) uud 1945.

E. Beberapa aturan undang-undang yang diujikan menciptakan ketidakpastian hukum karena bertentangan dengan undang - undang spesialis lain.

F. Undang-undang secara keseluruhan patut dibatalkan karena bertentangan dengan konstitusi

G. Penerapan pasal - pasal yang diujikan telah menimbulkan kerugian nyata bagi para pemohon dan masyarakat daerah

H. Permohonan pemeriksaan dan putusan secara cepat

V. PENUTUP

VI. PETITUM : Bahwa berdasarkan uraian, alasan, dan fakta

hukum di atas, para Pemohon memohon kepada Majelis Hakim Mahkamah Konstitusi untuk memutuskan: ....dst.

c) Alat Bukti : [2.2] Menimbang bahwa untuk membuktikan dalilnya, para Pemohon telah mengajukan alat bukti surat/tulisan yang diberi tanda bukti P- 1.A sampai dengan bukti P-35C sebagai berikut: .... dst.

d) Keterangan Ahli : Para Pemohon dalam persidangan tanggal 14 April 2016 dan/atau tanggal 28 April 2016 mengajukan 4 (empat) orang ahli, yakni Prof. Dr. M. Ryass Rasyid, MA, Dr. Indra Perwira, S.H., M.H., Dr.M. Rifqinizamy Karsayuda, S.H.,LL.M, dan Prof. Dr. Ir. H. Abrar Saleng, S.H., M.H, yang menyampaikan ....dst.

e) Saksi : para Pemohon dalam persidangan tanggal 28 April 2016 mengajukan 4 (empat) orang saksi, yakni Edy Alwi, Drs. Israr Dasuki Tasim, S.E., M.SI, Ilham, dan Abdul Rachman Atd, yang menyampaikan ....dst.

f) Jawaban Termohon: [2.3] Menimbang bahwa terhadap permohonan

g) para Pemohon tersebut, Presiden dalam persidangan tanggal 21 Maret 2016 menyampaikan keterangan lisan dan keterangan tertulis ....dst.

h) Replik : [2.4] Menimbang bahwa terhadap permohonan para Pemohon tersebut, Dewan Perwakilan Daerah dalam persidangan tanggal 14 April 2016 menyampaikan keterangan lisan dan keterangan tertulis ....dst.

i) Pertimbangan Hukum:

i. Kewenagan Mahkamah: [3.1] [3.2];

ii. Kedudukan Hukum (Legal Standing) Pemohon

iii. Pokok Permohonan: [3.8] - [3.13]

j) KONKLUSI : [4.1]-[4-7]

k) AMAR PUTUSAN: $1-6$

1) PENDAPAT BERBEDA (DISSENTING OPINIONS)

\section{Kualitas Putusan Hakim}

Muara dari trilogi yang harus dicapai hukum yaitu tentang nilai kepastian, nilai keadilan, dan nilai kemanfaatan salah satunya ada pada suatu putusan hakim yang menyidang suatu perkara. Ketiga hal tersebut memiliki batasan serta presentase yang abstrak antar komponen pada masing-masing hakim dalam mengambil keputusan. Hakim dijamin penuh untuk bebas merumuskan pertimbangan hukum berdasar undang-undang dalam setiap perkara yang ditanganinnya tanpa ada yang boleh mengintervensinnya. Hal ini senada dengan yang disampaiakan Bapak Soedikno Mertokoesumo yang menyatakan bahwa "Segala campur tangan dalam urusan peradilan oleh pihak-pihak lain di luar kekuasaan kehakiman dilarang, kecuali dalam halhal yang tersebut dalam undang-undang". ${ }^{10}$

Ada 2 (dua) aliran yang dapat mengelompokkan hakim dalam penggambilan suatu pertimbangan yang akan digunakan dalam memutus suatu perkara, yaitu aliran konservatif dan aliran progresif. Aliran konservatif lebih menekankan pada kepastian hukum dengan mengacu pada sumber hukum yang tertulis, sedangkan aliran progresif lebih menekankan pada keadilan dengan tidak hanya mengacu pada hukum tertulis saja, melainkan juga aspek sosial. Hal ini dipertegas dengan 2 (dua) pendapat pakar hukum berikut ini:

Aliran Konservatif yaitu putusan hakim yang di dasarkan semata mata ada ketentuan hukum tertulis (peraturan perundang-undang). Karakter ini dipengaruhi oleh aliran legisme yaitu aliran dalam ilmu hukum dan peradilan yang tidak mengakui hukum diluar yang tertulis/ undang-undang. Menurut aliran ini hukum identik dengan undang- undang,

\footnotetext{
${ }^{10}$ Soedikno Mertokoesumo, “Sistem Peradilan di Indonesia”, Jurnal Hukum FH-UII. No.9. Vol. 4 Oktober 1997.
} 
sedangkan kebiasaan dan ilmu pengetahuan hukum lainnya, dapat diakui sebagai hukum, apabila undang-undang menunjuknya. Aliran Progresif yaitu putusan hakim yang tidak semata-mata mendasarkan pada ketentuan hukum tertulis tetapi hakim harus pula mendasarkan pada pengetahuan dan pengalaman empiris yang dialaminya. ${ }^{11}$

Dari latar belakang aliran yang dianut hakim, hal ini menjadi salah satu sebab yang menjadikan adanya perbedaan pendapat dalam musyawarah majelis hakim sebelum memutus suatu perkara.

\section{Peraturan Daerah Kabupaten/Kota}

\section{Hierarki Peraturan Daerah Kabupaten/Kota}

Dalam tata hukum di Indonesia dikenal dengan adanya hirarki/tata urutan peraturan suatu peraturan perundang-undangan. Setiap peraturan perundang-undangan yang ada tidak boleh bertentangan dengan hierarki di atasnya. Hal ini sesuai dengan ketentuan berikut ini:

"Dalam ketentuan ini yang dimaksud dengan "hierarki" adalah penjenjangan setiap jenis Peraturan Perundang-undangan yang didasarkan pada asas bahwa Peraturan Perundang-undangan yang lebih rendah tidak boleh bertentangan dengan Peraturan Perundang-undangan yang lebih tinggi.", 12

Peraturan Daerah Kabupaten/Kota dalam undang-udang tersebut menempati urutan ke-7 yang bererti bahwa, semua yang diatur dalam setiap peraturan ini tidak buleh bertentangan dengan peraturan perundang-undangan di atasnya. Adapun secara berurutan hierarki peraturan perundang yang dimaksud adalah Undang-Undang Dasar Negara Republik Indonesia Tahun 1945, Ketetapan Majelis Permusyawaratan Rakyat, Undang-Undang/Peraturan Pemerintah Pengganti Undang-Undang, Peraturan Pemerintah,Peraturan Presiden, Peraturan Daerah Provinsi, dan Peraturan Daerah Kabupaten/Kota. ${ }^{13}$

Jadi dapat dikatakan bahwa Peraturan Daerah Kabupaten/Kota merupakan peraturan perundang-undangan paling rendah dalam hierarki peraturan perundang-undangan yang mempuyai materi muatan yang paling banyak dan memiliki tingkat fleksibilitas yang sedikit karena harus sesuai dan tiddak bertentangan dengan peraturan perundang-undangan yang berada diatasnya. Hal ini bisa dipahami dengan sudut pandang pendekatan Stufenbaudes Recht yang diungkapkan oleh Hans Kelsen bahwa:

"norma itu berjenjang jenjang dan berlapis-lapis dalam suatu susunan hierarki, norma yang di bawah berlaku, bersumber dan berdasar pada norma yang lebih tinggi, norma yang lebih tinggi berlaku, bersumber dan berdasar pada norma yang lebih tinggi lagi, demikian seterusnya sampai akhirnya berhenti pada suatu norma yang tertinggi yang disebut dengan norma dasar (Grundnorm)."14

Hal tersebut itulah yang kemudian kita pahami dengan asas lexsuperior derogat legiinferiori.

\section{Pembentukan Peraturan Daerah Kabupaten/Kota}

Pada prinsipnya, Peraturan Daerah Kabupaten/Kota merupakan peraturan perundang-undangan yang dibentuk oleh Dewan Perwakilan Rakyat Daerah Kabupaten/Kota (DPRD Kab./Kota) dengan persetujuan bersama Bupati/Walikota. Pembentukan peraturan ini di awali dengan adanya perencanaan pembentukan peraturan yang tertuang dalam prolegda Kab./Kota. Prolegda merupakan instrumen perencanaan program pembentukan Peraturan Daerah Peraturan Daerah Kabupaten/Kota yang disusun secara terencana, terpadu, dan sistematis.

Dalam Pembentukan Peraturan Daerah Kabupaten/Kota setidaknya memuat tiga landasan yaitu landasan filosofis, landasan sosiologis, dan landasan yuridis. Landasan filosofis merupakan pertimbangan yang menggambarkan bahwa peraturan yang dibentuk harus mempertimbangkan pandangan hidup, kesadaran dan cita hukum yang meliputi suasana kebatinan serta falsafah bangsa Indonesia yang bersumber dari Pancasila dan Pembukaan Undang-Undang Dasar Negara Republik Indonesia Tahun 1945.

Landasan berikutnya adalah landasan sosiologis. Hamzah Halim dan Kemal Redinho Syahrul Putera dalam bukunya menjelaskan bahwa Landasan sosiologis merupakan landasan yang terdiri atas fakta-fakta yang merupakan tuntutan kebutuhan masyarakat yang mendorong perlunya pembuatan perundang-undangan (perda), yaitu bahwa ada sesuatu yang pada dasarnya dibutuhkan oleh masyarakat sehingga perlu pengaturan. ${ }^{15}$ Dari pendapat tersebut dapat dipahami bahwa landasan sosiologis ini merupakan pertimbangan yang menggambarkan bahwa peraturan perundang-undangan yang dibentuk diadakan untuk memenuhi kebutuhan masyarakat dalam berbagai aspek.

Berikutnya adalah landasan yuridis. Riawan Tjandra dan Kresno Budi Darsono mengatakan bawa landasan yuridis dari penyusunan peraturan perundang-undangan meliputi tiga hal yaitu $:{ }^{16}$

\footnotetext{
${ }^{11}$ Sudikno Mertokusumo \& A.Pitlo,1993, Bab-Bab tentang Penemuan Hukum, Jakarta: Citra Aditya Bakti, hal. 10.

${ }^{12}$ Penjelasan Pasal 7 Ayat (2) Undang-Undang Nomor 12 Tahun 2011 Tentang pembentukan Peraturan Perundang-Undangan Lembaran Negara Republik Indonesia Tahun 2011 Nomor 82

${ }^{13}$ Pasal 7 Ayat (2) Undang-Undang Nomor 12 Tahun 2011 Tentang pembentukan Peraturan Perundang-Undangan Lembaran Negara Republik Indonesia Tahun 2011 Nomor 82.

${ }^{14}$ Hans Kelsen dalam bukunya yang berjudul General Theory of Law and State, sebagaimana dikutip dalam Maria Farida Indrati, Ibid., hlm.21-22.

${ }^{15}$ Hamzah Halim dan Kemal Redindo Syahrul Putera,Cara Praktis Menyusun dan Merancang Peraturan Daerah (Suatu K ajian Teoritis dan Praktis Disertai Manualnya): Konsepsi Teoritis Menuju Artikulasi Empiris ,(Jakarta: Prenada Media Group, 2009), h.25

${ }^{16}$ W. RiawanTjandra dan Kresno Budi Darsono, Legislative Drafting, Atma Jaya, Yogyakata, 2009, hal.81
} 
1. Kewenangan dari pembuat peraturan perundang-undangan.

2. Kesesuaian bentuk atau jenis peraturan perundang-undangan dengan materi yang akan diatur.

3. Keharusan mengikuti tata cara tertentu.

\section{E. Tugas pokok dan fungsi Menteri Dalam Negeri}

Kementerian Dalam Negeri Republik Indonesia disingkat Kemendagri RI adalah kementerian dalam Pemerintah Indonesia yang membidangi urusan dalam negeri. Kementerian Dalam Negeri berada di bawah dan bertanggung jawab kepada Presiden. Berdasarkan Peraturan Presiden Nomor 11 Tahun 2015 tentang Kementerian Dalam Negeri ${ }^{17}$, Kementerian Dalam Negeri mempunyai tugas menyelenggarakan urusan di bidang pemerintahan dalam negeri untuk membantu Presiden dalam menyelenggarakan pemerintahan negara. Dalam melaksanakan tugas tersebut, Kementerian Dalam Negeri menyelenggarakan fungsi:

1. Perumusan, penetapan, dan pelaksanaan kebijakan di bidang politik dan pemerintahan umum, otonomi daerah, pembinaan administrasi kewilayahan, pembinaan pemerintahan desa, pembinaan urusan pemerintahan dan pembangunan daerah, pembinaan keuangan daerah, serta kependudukan dan pencatatan sipil, sesuai dengan ketentuan peraturan perundang-undangan;

2. Koordinasi pelaksanaan tugas, pembinaan, dan pemberian dukungan administrasi kepada seluruh unsur organisasi di lingkungan Kementerian Dalam Negeri;

3. Pengelolaan barang milik/kekayaan negara yang menjadi tanggung jawab Kementerian Dalam Negeri;

4. Pengawasan atas pelaksanaan tugas di lingkungan Kementerian Dalam Negeri;

5. Pelaksanaan bimbingan teknis dan supervisi atas pelaksanaan urusan Kementerian Dalam Negeri di daerah;

6. Pengoordinasian, pembinaan dan pengawasan umum, fasilitasi, dan evaluasi atas penyelenggaraan pemerintahan daerah sesuai dengan ketentuan peraturan perundang-undangan;

7. Pelaksanaan penelitian dan pengembangan di bidang pemerintahan dalam negeri;

8. Pelaksanaan pengembangan sumber daya manusia di bidang pemerintahan dalam negeri;

9. Pelaksanaan kegiatan teknis dari pusat sampai ke daerah; dan

Pelaksanaan dukungan yang bersifat substantif kepada seluruh unsur organisasi di lingkungan Kementerian Dalam Negeri.

\section{III.METODE PENELITIAN}

\section{A. Tipe penelitian}

Dalam penelitian pada umumnya dibedakan antara data yang diperoleh secara langsung dari masyarakat dan bahan-bahan pustaka. "Penelitian hukum yang dilakukan dengan cara meneliti bahan pustaka atau data sekunder belaka, dapat dinamakan penelitian hukum normatif atau penelitian hukum kepustakaan (di samping adanya penelitian hukum sosiologis atau empiris yang terutama meneliti data primer)." 18 Tipe penelitian yang dipakai dalam penelitian ini adalah yuridis normatif, yaitu penelitian yang difokuskan untuk mengkaji kaidah-kaidah atau norma-norma dalam hukum positif. Tipe penelitian yuridis normatif tidak dimulai dari suatu hipotesis, tetapi penelitian ini berangkat dari pengidentifikasian fakta hukum dan mengeleminir hal-hal yang tidak relevan untuk selanjutnya ditetapkan sebagi isu hukum yang hendak dipecahkan.Hal ini seperti yang diungkapkan Peter Mahmud Marzuki yang berpendapat sebagai berikut "Oleh karena secara karakteristik berbeda antara keilmuan hukum dan keilmuan yang bersifat diskriptif tersebut, penelitian hukum tidak perlu dimulai dengan hipotesis. Dengan demikian istilah variabel bebas dan variabel terikat tidak dikenal dalam penelitian hukum."19

\section{B. Pendekatan masalah penelitian}

Untuk mendapatkan informasi dari berbagai aspek mengenai isu yang sedang dicoba untuk dicari jawabanya diperlukan adanya pendekatan masalah penelitian. Pendekatan yang digunakan dalam penelitian ini adalah gabungan dari dua metode pendekatan yaitu pendekatan undang-undang (statute approach), dan pendekatan asas-asas hukum (legal principle approach).

Pendekatan undang-undang (statute approach) dilakukan dengan menelaah semua undang-undang dan regulasi yang bersangkut paut dengan isu hukum yang sedang ditangani. ${ }^{20}$ Dalam hal ini penulis akan melakukan telaah terhadap UndangUndang Nomor 23 Tahun 2014 tentang Pemerintahan Daerah, terkait pasal-pasal yang dibatalkan oleh mahkamah konstitusi dalam putusan perkara Nomor: 137/PUU-XIII/2015. Pendekatan masalah penelitian yang terakhir adalah pendekatan asas-asas hukum (legal principle approach). Penelitian terhadap asas-asas hukum merupakan suatu penelitian filosofis, oleh karena asas hukum merupakan unsur ideal dari hukum. ${ }^{21}$ Pendekatan asas-asas hukum dilakukan dengan cara mengidentifikasi dan menganalisis asas-asas hukum yang berkembang dalam penelitian ini terutama yang tercantum dalam pertimbangan putusan dan dalam dissenting opinions dalam putusan perkara mahkamah konstitusi yang di jadikan isu hukum dalam penelitian ini.

\footnotetext{
${ }^{17}$ Peraturan Presiden Nomor 11 Tahun 2015 Tentang Kementerian Dalam Negeri Lembaran Negara Republik Indonesia Tahun 2015 Nomor 12

18 Soerjono Soekanto, Penelitian Hukum Normatif, RajawaliPers, Jakarta, Maret 1985.Hal 13

${ }^{19}$ Peter Mahmud Marzuki, Penelitian Hukum, Kencana, Jakarta, cetakan ke-6, Februari 2010.hal 35

${ }^{20}$ Ibid, hal. 93

${ }^{21}$ Soerjono Soekanto, Penelitian Hukum Normatif, RajawaliPers, Jakarta, Maret 1985.Hal 62
} 
Website : http://yustisia.unmermadiun.ac.id/index.php/yustisia

Pendekatan asas-asas hukum digunakan untuk mengungkapkan filosifis dan pola pikir masing-masing hakim yangg menyidangkan perkara uji materiil terhadap perkara yang di atas.

\section{Sumber-sumber bahan penelitian}

Untuk menunjang dalam menjawab isu hukum yang telah dirumuskan dan sekaligus memberikan preskripsi mengenai apa yang seharusnya, diperlukan adanya sumber-sumber bahan penelitian. Sumber-sumber bahan penelitian dalam metode penelitian yuridis normatif berbeda dengan metode penelitian hukum lainnya. Pada penelitian hukum normatif, bahan pustaka merupakan data dasar yang dalam (ilmu) penelitian digolongkan sebagai data sekunder. ${ }^{22}$ Sumber-sumber bahan penelitian hukum tersebut dapat dikualifikasikan menjadi sumber bahan hukum primer dan sumber bahan sekunder serta sumber bahan non-hukum (jika diperlukan dalam memecahkan isu hukum).

Bahan hukum primer merupakan bahan hukum yang bersifat autoritatif artinya mempunyai otoritas. Bahan - bahan hukum primer terdiri dari perundang-undangan, catatan resmi atau risalah dalam pembuatan perundang-undangan dan putusan putusan hakim. ${ }^{23}$ Bahan hukum yang digunakan dalam penelitian ini adalah:

1. Undang-Undang Dasar Republik Indonesia Tahun 1945;

2. Undang-Undang Republik Indonesia Nomor 5 tahun 2004 Perubahan Atas Undang-Undang Nomor 14 Tahun 1985 Tentang Mahkamah Agung

3. Undang - Undang Nomor 12 Tahun 2011 Tentang Pembentukan Peraturan Perundang - Undangan;

4. Undang - Undang Nomor 23 Tahun 2014 tentang Pemerintahan Daerah;

5. Undang-Undang Republik Indonesia Nomor 48 Tahun 2009 Tentang Kekuasaan Kehakiman.

6. Peraturan Presiden Nomor 11 Tahun 2015 Tentang Kementerian Dalam Negeri Lembaran Negara Republik Indonesia Tahun 2015 Nomor 12

7. Putusan Mahkanah Konstitusi Perkara Nomor 137/PUU-XIII/2015 tanggal 4 April 2017 mengenai putusan atas permohonan uji materiil undang-undang Pemerintah Daerah.

Sumber bahan penelitian selanjutnya adalah sumber bahan hukum sekunder, yaitu berupa semua publikasi tentang hukum yang bukan merupakan dokumen resmi. Publikasi tentang hukum meliputi buku - buku teks, kamus - kamus hukum, jurnal jurnal hukum, dan komentar - komentar atas putusan pengadilan. ${ }^{24}$

Sebagai bahan hukum sekunder yang terutama adalah buku - buku hukum termasuk skripsi, tesis, dan desertasi hukum dan jurnal - jurnal hukum (termasuk yang on-line). Di samping itu juga, kamus - kamus hukum ,dan komentar - komentar atas putusan pengadilan (misalnya Himpunan Landmark Decisions Sudargo Gautama). Kegunaan bahan hukum sekunder adalah memberikan kepada peneliti semacam "petunjuk" kearah mana peneliti melangkah. Apabila tulisan itu berupa tesis, disertasi atau artikel di jurnal hukum, boleh jadi tulisan itu memberi inspirasi bagi peneliti untuk menjadi titik anjak dalam memulai penelitian. Bagi kalangan praktisi, bahan hukum sekunder ini bukan tidak mungkin sebagai panduan berfikir dalam menyusun argumentasi yang akan diajukan dalam persidangan atau memberikan pendapat hukum. ${ }^{25}$

\section{Tahapan penelitian}

1. Mengidentifikasi fakta hukum dan mengeleminir hal - hal yang tidak relevan untuk menetapkan isu hukum yang hendak dipecahkan;

2. Pengumpulan bahan - bahan hukum yang relevansi dengan isu hukum yang dikupas sehingga mampu untuk memecahkan isu hukum tersebut;

3. Melakukan telaah atas isu hukum yang diajukan berdasar bahan - bahan yang telah dikumpulkan;

4. Menarik kesimpulan dalam bentuk argumentasi yang menjawab isu hukum;

Memberikan perskripsi berdasarkan argumentasi yang dibangun di dalam kesimpulan.

\section{IV.HASIL PENELITIAN DAN PEMBAHASAN}

\section{A. Analisa pertimbangan hakim dalam amar putusan perkara nomor: 137/PUU-XIII/2015}

Suatu vonis hakim yang tertera dalam suatu putusan perkara ibarat kekokohan sebuah batang pohon. Batang yang kokoh memerlukan akar yang baik untuk mengikat dan menyuplai nutrisi, dan pertimbangan hukum dalam putusan perkara inilah ibarat akarnya. Dapat diartikan bahwa, suatu kualitas vonis putusan hakim dalam suatu perkara ditentunkan seperti apa pertimbangan hukum yang dibangun oleh hakim. Putusan perkara nomor: 137/PUU-XIII/2015 merupakan putusan dari 9 (sembilan) orang hakim mahkamah konstitusi terkait uji materiil tentang Menteri Dalam Negeri dapat membatalkan perda kabupaten/kota selama gubernur tidak bisa menjalankan ketentuan pasal 251 ayat (2) UU Pemda 2014.

Dalam amar putusan perkara tersebut, majelis hakim memutuskan untuk sebagian dari apa yang di mohonkan para pemohon yang pada intinya menyatakan bahwa: bertentangan dengan Undang-Undang Dasar Negara Republik Indonesia Tahun 1945 dan

\footnotetext{
${ }^{22}$ Ibid, hal.24

${ }^{23}$ Peter Mahmud Marzuki,Penelitian Hukum,Kencana,Jakarta, cetakan ke-6, Februari 2010,hal.142

${ }^{24}$ Ibid, Hal. 142

${ }^{25}$ Ibid, Hal.155
} 
tidak mempunyai kekuatan hukum mengikat beberapa frasa dalam pasal Undang-Undang Nomor 23 Tahun 2014 tentang Pemerintahan Daerah, yaitu :

1. frasa "Perda Kabupaten/Kota dan" dalam Pasal 251 ayat (2) dan ayat (4);

2. frasa "Perda Kabupaten/Kota dan/atau" dalam Pasal 251 ayat (3);

3. frasa "penyelenggara Pemerintah Daerah kabupaten/kota tidak dapat menerima keputusan pembatalan Perda Kabupaten/Kota" Pasal 251 ayat (8);

4. frasa "Perda Kabupaten/Kota atau" dalam Pasal 251 ayat (8). Beberapa pertimbangan hakim terkait pokok permohonan dalam memutus juridical review tersebut adalah sebagai berikut:

1. Bahwa pengaturan pembagian klasifikasi urusan pemerintahan dalam Pasal 9; Pasal 11; Pasal 12; Pasal 13; Pasal 14 ayat (1), ayat (2), ayat (3), dan ayat (4); UU Pemda merupakan bentuk sentralisasi kekuasaan, pembatasan kewenangan pemerintahan daerah kabupaten/kota, dan model otonomi fiktif, oleh karenanya bertentangan dengan Pasal 18 ayat (1) UUD 1945 yang menyebutkan Negara Kesatuan Republik Indonesia dibagi atas (bukan terdiri dari) daerah Provinsi dan Kabupaten/Kota, Pasal 18 ayat (2) UUD 1945, dan teori residu sebagaimana dianut dalam Pasal 18 ayat (5), Pasal 18 ayat (6), dan Pasal 18A ayat (1) UUD 1945;

Pertimbangan ini merupakan bagian tafsir Mahkamah Konstitusi terkait pokok perkara yang pada intinya menekankan pasal dalam UU pemda tersebut di atas bertentangan dengan UUD 1945 pada pasal-pasal tersebut di atas.

2. Bahwa pasal-pasal yang diujikan dalam UU Pemda mengebiri hak para Pemohon yang mendapatkan mandat untuk menjalankan roda pemerintahan daerah, memajukan, dan menyejahterakan masyarakat daerahnya berdasarkan prinsip otonomi daerah seluas-luasnya, sehingga berimplikasi pada sumber pendapatan dan keuangan daerah masing-masing;

Hal tersebut terjadi karena hakim konstitusi sependapat dengan apa yang diajukan pemohon, bahwa keterlibatan Menteri Dalam Negeri yang memegang kewenangan atas nama Pemerintah Pusat untuk dapat membatalkan Peraturan Daerah Kabupaten/Kota dapat mengganggu visi dan misi daerah yang bersangkutan.

3. Bahwa dengan tidak dilibatkannya pemerintahan kabupaten/kota dalam pengelolaan sumber daya alam dan mineral di daerahnya sendiri sebagaimana ditentukan dalam Pasal 14 ayat (1), ayat (2), ayat (3); Pasal 27 ayat (1) dan ayat (2); dan Pasal 28 ayat (1) dan ayat (2) UU Pemda menyebabkan ketidakadilan dan ketidakselarasan, sehingga bertentangan dengan Pasal 18 ayat (2) UUD 1945 yang menegaskan pengelolaan bidang tersebut berdasarkan pada prinsip keadilan dan keselarasan;

Asas otonomi dan pembantuan sebagaimana amanat UUD 1945 Pasal 18 Ayat (2) menjadi dasar bahawa pasal-pasal UU Pemda tersebut di atas tidak tepat dan bertentangan. Mengacu pada hierarki dalam UU tentang Peraturan PerundangUndangan, pasal UU Pemda tersebut tidak berlaku lagi.

4. Bahwa mekanisme pembatalan Perda dan Perkada yang ditentukan oleh UU Pemda melalui gubernur serta pengajuan keberatan pembatalannya kepada Menteri selain menciptakan ketidakpastian hukum juga bertentangan dengan pembagian trias politika karena hak pembuatan produk perundang-undangan oleh pemerintahan daerah yang diberikan oleh Pasal 18 ayat (6) UUD 1945 hanya dapat dibatalkan oleh lembaga yudikatif yang diberikan kewenangan untuk membatalkan itu, yakni Mahkamah Agung [vide Pasal 24A ayat (1) UUD 1945;

5. Keberadaan Pasal 251 ayat (2) dan ayat (3) UU Pemda yang memberi wewenang kepada Menteri dan gubernur sebagai wakil Pemerintah Pusat untuk membatalkan Perda Kabupaten/Kota yang bertentangan dengan ketentuan peraturan perundang-undangan yang lebih tinggi, selain menyimpangi logika dan bangunan negara hukum Indonesia sebagaimana amanah Pasal 1 ayat. UUD 1945 juga menegasikan peran dan fungsi Mahkamah Agung sebagai lembaga yang berwenang melakukan pengujian peraturan perundang-undangan di bawah Undang-Undang in casu Perda Kabupaten/Kota sebagaimana ditegaskan dalam Pasal 24A ayat (1) UUD 1945.

6. Pembatalan Perda Kabupaten/Kota melalui keputusan gubernur sebagai wakil Pemerintah Pusat sebagaimana dimaksud dalam Pasal 251 ayat (4) UU Pemda, menurut Mahkamah tidak sesuai dengan rezim peraturan perundang-undangan yang dianut Indonesia. Pasal 7 ayat (1) dan Pasal 8 UU 12/2011 tidak mengenal keputusan gubernur sebagai salah satu jenis dan hierarki peraturan perundang-undangan. Dengan demikian kedudukan keputusan gubernur bukanlah bagian dari rezim peraturan perundang-undangan, sehingga tidak dapat dijadikan produk hukum untuk membatalkan Perda Kabupaten/Kota.

\section{B. Perskripsi dasar dissenting Opinion 4 (empat) orang anggota majelis hakim Mahkamah Konstitusi dalam putusan perkara nomor: 137/PUU-XIII/2015 dikaitkan dengan UUD 1945}

Putusan ini mengakibatkan Menteri Dalam Negeri tidak lagi mempunyai kewenangan untuk membatalkan Peraturan Daerah Kabupaten/Kota. Adapun dalam putusan MK khusus terhadap dalil para Pemohon dalam pengujian Pasal 251 ayat (2), ayat (3), ayat (4), dan ayat (8) Undang-Undang Nomor 23 Tahun 2014 tentang Pemerintahan Daerah (UU Pemda), Hakim Konstitusi Arief Hidayat, I Dewa Gede Palguna, Maria Farida Indrati, dan Manahan MP Sitompul berpendapat bahwa norma UU Pemda tersebut tidak bertentangan dengan UUD 1945, dengan penjelasan sebagai berikut :

1. Mengacu kepada penjelasan umum Undang-Undang Pemda yang menyatakan Pemberian otonomi yang seluas-luasnya kepada Daerah dilaksanakan berdasarkan prinsip negara kesatuan. Dalam negara kesatuan kedaulatan hanya ada pada pemerintah negara atau pemerintah nasional dan tidak ada kedaulatan pada Daerah. Oleh karena itu, seluas apapun otonomi yang diberikan kepada Daerah, tanggung jawab akhir penyelenggaraan Pemerintahan Daerah akan tetap ada di tangan Pemerintah Pusat. Untuk itu Pemerintahan Daerah pada negara kesatuan merupakan satu kesatuan dengan Pemerintahan 
Nasional. Pada bagian lain dari Penjelasan Umum UU Pemda ditegaskan pula, antara lain, Daerah sebagai satu kesatuan masyarakat hukum yang mempunyai otonomi berwenang mengatur dan mengurus daerahnya sesuai aspirasi dan kepentingan masyarakatnya sepanjang tidak bertentangan dengan tatanan hukum nasional dan kepentingan umum.

2. Dalam menilai konstitusionalitas Pasal 251 UU Pemda, haruslah senantiasa bertolak dari pemahaman bahwa kewenangan Kepala Daerah dan DPRD untuk membentuk Peraturan Daerah adalah kewenangan atribusi (attributie van wetgevingsbevoegheid) yang hanya dapat diberikan dan diadakan oleh Undang-Undang Dasar dan Undang-Undang, dalam hal ini Pasal 18 ayat (6) UUD 1945 dan Pasal 236 UU Pemda. Peraturan daerah bukanlah peraturan delegasi dari UndangUndang, dalam hal ini UU Pemda, sebab jika demikian halnya maka hal itu menyalahi prinsip delegatie van wetgevingsbevoegheid, yaitu pelimpahan kewenangan membentuk peraturan perundang-undangan dari peraturan yang lebih tinggi kepada peraturan yang lebih rendah. Jika Peraturan Daerah dianggap sebagai peraturan delegasi dari Pemda berarti telah terjadi pelimpahan kewenangan secara tidak berjenjang, dalam hal ini pelimpahan kewenangan tersebut melampaui atau melompati Peraturan Pemerintah, Peraturan Presiden, Peraturan Menteri, sehingga tidak sesuai dengan prinsip utama pelimpahan wewenang.

3. Hakikat pembatalan dalam hukum administrasi adalah tindakan hukum dalam hal keputusan yang dibuat pejabat pemerintahan mengandung cacat hukum atau tidak lagi memenuhi syarat, formal maupun substantif. Tujuannya adalah untuk melindungi pihak-pihak dan masyarakat yang dirugikan atas sebuah keputusan pemerintahan dan memulihkan kembali atau menegasikan akibat hukum yang timbul dari sebuah keputusan. Pembatalan dapat dilakukan oleh pejabat yang membuat keputusan, atasan pejabat yang membuat keputusan, atau pengadilan (dalam hal ini Pengadilan Tata Usaha Negara). Meskipun, dalam hukum administrasi tindakan pembatalan digunakan terhadap keputusan (beschikking), dalam konteks permohonan a quo, rasionalitas hukumnya dapat diterima apabila pembatalan diberlakukan terhadap peraturan daerah atau peraturan kepala daerah. Sebab, secara konstitusional, Presiden adalah penangggung jawab pemerintahan tertinggi. Dengan demikian, secara implisit, adalah kewajiban presiden untuk mengambil tindakan terhadap produk hukum penyelenggara pemerintahan yang mengandung cacat, dalam hal ini cacat itu adalah bahwa produk hukum penyelenggara pemerintahan itu bertentangan dengan peraturan perundang-undangan yang lebih tinggi, kepentingan umum, dan/atau kesusilaan.

4. Menurut Pasal 4 UUD 1945, Presiden adalah pemegang kekuasaan pemerintahan. Oleh karena itu, tepatlah rumusan yang terdapat dalam Pasal 1 angka 1 UU Pemda yang mengatakan Pemerintah Pusat adalah Presiden Republik Indonesia yang memegang kekuasaan pemerintahan negara Republik Indonesia yang dibantu oleh Wakil Presiden dan menteri sebagaimana dimaksud dalam Udang-Undang Dasar Negara Republik Indonesia Tahun 1945. Dengan kata lain, penanggung jawab keseluruhan pelaksanaan pemerintahan adalah Presiden. Hal ini dikarenakan Indonesia adalah negara kesatuan, sebagaimana ditegaskan dalam Pasal 1 ayat (1) UUD 1945. Pemerintahan daerah adalah bagian dari pelaksanaan kekuasaan pemerintahan. Sehingga, meskipun berdasarkan Pasal 18 UUD 1945 daerah diberi otonomi yang seluas-luasnya untuk juga menyelenggarakan pemerintahan, penanggung jawab terakhir penyelenggaraan pemerintahan itu tetap Presiden. Karena itu, Presiden berkepentingan dan berdasar hukum untuk memastikan bahwa penyelenggaraan pemerintahan yang berada di bawah tanggung jawabnya, in casu pemerintahan daerah, tidak bertentangan dengan peraturan perundang-undangan yang lebih tinggi, ketertiban umum, dan/atau kesusilaan. Dengan demikian adalah konstitusional apabila Presiden, melalui Menteri dan gubernur sebagai wakil Pemerintah Pusat di daerah, diberi kewenangan untuk membatalkan peraturan daerah.

5. Pemerintahan Daerah, menurut Pasal 1 angka 2 UU Pemda, adalah penyelenggaraan urusan pemerintahan oleh pemerintah daerah dan dewan perwakilan rakyat daerah menurut asas otonomi dan tugas pembantuan dengan prinsip otonomi seluasluasnya dalam sistem dan prinsip Negara Kesatuan Republik Indonesia sebagaimana dimaksud dalam Undang-Undang Dasar Negara Republik Indonesia Tahun 1945. Sementara itu, kepala daerah dan dewan perwakilan rakyat daerah, menurut Pasal 1 angka 2 dan angka 3 UU Pemda, adalah sama-sama sebagai unsur penyelenggara Pemerintahan Daerah. Adapun Peraturan daerah, berdasarkan Pasal 236 ayat (2) UU Pemda, adalah produk bersama dewan perwakilan rakyat daerah dan kepala daerah yang materinya dapat memuat penyelenggaraan Otonomi Daerah, penjabaran lebih lanjut ketentuan peraturan perundang-undangan yang lebih tinggi, atau materi muatan lokal sesuai dengan ketentuan peraturan perundang-undangan. Dengan kata lain, materi muatan peraturan daerah adalah materi yang bersubstansikan urusan pemerintahan. Dengan demikian, peraturan daerah adalah produk bersama dari unsur-unsur pemerintahan daerah yang materi muatannya adalah urusan pemerintahan. Sedangkan Urusan Pemerintahan, sebagaimana ditegaskan dalam Pasal 1 angka 5 UU Pemda, adalah kekuasaan pemerintahan yang menjadi kewenangan Presiden yang pelaksanaannya dilakukan oleh kementerian negara dan penyelenggara Pemerintahan Daerah untuk melindungi, melayani, memberdayakan, dan menyejahterakan masyarakat Oleh karena itu, mendalilkan norma yang memberi kewenangan kepada Presiden (melalui Menteri dan gubernur selaku wakil Pemerintah Pusat) untuk membatalkan Perda dan peraturan kepala daerah sebagai norma yang inkonstitusional sama artinya dengan mengatakan bahwa pemerintahan daerah bukan bagian dari kekuasaan pemerintahan yang tanggung jawab terakhirnya ada di tangan presiden. Demikian pula halnya dalil bahwa norma yang memberi kewenangan kepada Presiden (melalui Menteri dan gubernur selaku wakil Pemerintah Pusat) untuk membatalkan Perda sebagai norma yang inkonstitusional dengan alasan bahwa DPRD adalah lembaga legislatif daerah adalah sama artinya dengan menyatakan bahwa DPRD bukan bagian dari unsur penyelenggaraan pemerintahan daerah.

6. Tindakan pembatalan harus dibedakan dengan judicial review atau pengujian peraturan peraturan perundang-undangan. Kewenangan judicial review adalah bagian dari kewenangan kekuasaan peradilan atau kekuasaan kehakiman yang dapat 
dimohonkan oleh pihak-pihak yang merasa dirugikan oleh berlakunya suatu peraturan perundang-undangan, in casu peraturan daerah, dikarenakan peraturan perundang-undangan dimaksud bertentangan dengan peraturan perundangundangan yang lebih tinggi. Sementara itu, sebagaimana telah diuraikan di atas, pembatalan adalah bagian dari kekuasaan pemerintahan (eksekutif). Oleh karena itu, UU Pemda yang memberikan kewenangan kepada Presiden (melalui Menteri dan gubernur) untuk membatalkan peraturan daerah dan peraturan kepala daerah tidaklah dimaksudkan untuk menggantikan atau mengambil-alih kewenangan judicial review yang berada di tangan pemegang kekuasaan peradilan atau kehakiman. Dengan kata lain, UU Pemda tidak menghalangi atau menghapuskan hak pihak-pihak yang merasa dirugikan oleh berlakunya suatu peraturan daerah atau peraturan kepala daerah untuk mengajukan judicial review.

Dari ke enam hal di atas, pada pokoknya hakim konstitusi yang menyatakan pendapat berbeda tersebut mengemukakan terkait permohonan pemohon yang memohon pengujian konstitusionalitas Pasal 251 ayat (2), ayat (3), ayat (4), dan ayat (8) Undang-Undang Pemda seharusnya di tolak. Adapun klausula pasal yang di maksud sebagai berikut:

1. Pasal 251 ayat (2)

Perda Kabupaten/Kota dan peraturan bupati/wali kota yang bertentangan dengan ketentuan peraturan perundang- undangan yang lebih tinggi, kepentingan umum, dan/atau kesusilaan dibatalkan oleh gubernur sebagai wakil Pemerintah Pusat.

2. Pasal 251 ayat (3)

Dalam hal gubernur sebagai wakil Pemerintah Pusat tidak membatalkan Perda Kabupaten/Kota dan/atau peraturan bupati/wali kota yang bertentangan dengan ketentuan peraturan perundang - undangan yang lebih tinggi, kepentingan umum, dan/atau kesusilaan sebagaimana dimaksud pada ayat (2), Menteri membatalkan Perda Kabupaten/Kota dan/ atau peraturan bupati/wali kota.

3. Pasal 251 ayat (4)

Pembatalan Perda Provinsi dan peraturan gubernur sebagaimana dimaksud pada ayat (1) ditetapkan dengan keputusan Menteri dan pembatalan Perda Kabupaten/Kota dan peraturan bupati/walikota sebagaimana dimaksud pada ayat (2) ditetapkan dengan keputusan gubernur sebagai wakil Pemerintah Pusat

4. Pasal 251 ayat (8)

Dalam hal penyelenggara Pemerintahan Daerah kabupaten/kota tidak dapat menerima keputusan pembatalan Perda Kabupaten/Kota dan bupati/wali kota tidak dapat menerima keputusan pembatalan peraturan bupati/wali kota sebagaimana dimaksud pada ayat (4) dengan alasan yang dapat dibenarkan oleh ketentuan peraturan perundang-undangan, bupati/wali kota dapat mengajukan keberatan kepada Menteri paling lambat 14 (empat belas) Hari sejak keputusan pembatalan Perda Kabupaten/Kota atau peraturan bupati/wali kota diterima.

\section{KESIMPULAN}

\section{A. Kesimpulan}

Dalam pertimbangan mahkamah konstitusi yang tersusun dan tersaji dalam naskah putusan, serta menjadi dasar dari apa yang tertuang dalam amar putusan, terdapat dua hal inti yang tertafsir. Pertama, penafsiran mahkamah terhadap arti kekuasaan pemerintah daerah. Mahkamah memperkuat penyebutan dalam UUD 1945 yang menyatakan bahwa Negara Kesatuan Republik Indonesia dibagi atas daerah Provinsi dan Kabupaten/Kota. Klausa "dibagi atas" dipertegas oleh mahkamah dengan kata "bukan terdiri dari". Hal ini berarti, adanya pemerintahan provinsi dan pemerintahan Kabupaten/ Kota mempunnyai tugas dan wewenang sendiri-sendiri sesuai yang diatur peraturan perundang-undangan. Kedua, menyambung terkait peraturan perundangundangan yang seperti apa, mahkamah memberi tafsir bahwa Pembatalan Perda Kabupaten/Kota melalui keputusan gubernur sebagai wakil Pemerintah Pusat tidak dapat dibenarkan, karena pembatalan tersebut merupakan ranah dari mekanisme pembatalan olah yudikatif, yaitu kewenangan Mahkamah Agung.

Pendapat berbeda/dissenting opinion empat hakim Mahkamah Konstitusi mengemukakan terkait permohonan pemohon yang memohon pengujian konstitusionalitas Pasal 251 ayat (2), ayat (3), ayat (4), dan ayat (8) Undang-Undang Pemda seharusnya di tolak, kurang tepat. Karena mengacu pada pertimbangan putusan sudah jelas bahwa pemohon mempunyai kedudukan hukum dalam melakukan uji konstitusionalitas pada pasal tersebut.

\section{B. Saran}

Dari isu hukum berupa Penganalisisan Dissenting Opinion 4 (empat) orang anggota majelis hakim dalam putusan perkara nomor: 137/PUU-XIII/2015, kemudian sudah di telaah dengan bahan hukum yang relevan, dan kemudian telah ditarik suatu kesimpulan yang normatif, maka dengan ini disampaikan argumentasi dari hasil penelitian (perskripsi) yang sudah dilakukan yaitu, hendaknya suatu dissenting opinion/pendapat berbeda hakim mahkamah konstitusi lebih teliti lagi dalam mengemukakan hak tersebut.

\section{VI.DAFTAR PUSTAKA}

Hamzah Halim dan Kemal Redindo Syahrul Putera,Cara Praktis Menyusun dan Merancang Peraturan Daerah (Suatu K ajian Teoritis dan Praktis Disertai Manualnya): Konsepsi Teoritis Menuju Artikulasi Empiris , (Jakarta: Prenada Media Group, 2009).

Hans Kelsen dalam bukunya yang berjudul General Theory of Law and State, sebagaimana dikutip dalam Maria Farida Indrati.

Mahkamah Agung RI, Pedoman Perilaku Hakim (code of conduct), Kode Etik Hakim Dan Makalah Berkaitan, Pusdiklat MA RI, Jakarta, 2006.

Peraturan Presiden Nomor 11 Tahun 2015 Tentang Kementerian Dalam Negeri Lembaran Negara Republik Indonesia Tahun 2015 Nomor 12 
Website : http://yustisia.unmermadiun.ac.id/index.php/yustisia

Peter Mahmud Marzuki, Penelitian Hukum, Kencana, Jakarta, cetakan ke-6, Februari 2010.

Soedikno Mertokoesumo, "Sistem Peradilan di Indonesia", Jurnal Hukum FH-UII. No.9. Vol. 4 Oktober 1997

Sudikno Mertokusumo \& A.Pitlo,1993, Bab-Bab tentang Penemuan Hukum, Jakarta: Citra Aditya Bakti.

Soerjono Soekanto, Penelitian Hukum Normatif, RajawaliPers, Jakarta, Maret 1985.

Undang-Undang Nomor 48 Tahun 2009 Tentang Kekuasaan Kehakiman, Lembaran Negara Nomor 157 Tahun 2009;Tambahan Lembaran Negara Nomor 5076

Undang-Undang Nomor 12 Tahun 2011 Tentang pembentukan Peraturan Perundang-Undangan Lembaran Negara Republik Indonesia Tahun 2011 Nomor 82

W. RiawanTjandra dan Kresno Budi Darsono, Legislative Drafting, Atma Jaya, Yogyakata, 2009.

www.jimlyschool.com/read/analisis/238/kedudukan-mahkamah-konstitusi-dalam-struktur-ketatanegaraan-indonesia/ 